\title{
BAREVNÝ TEST CESTY PRO DĚTI Recenze metody
}

\author{
Autoři ReCEnZe: Simona GalbaVÁ ${ }^{1}$, PAVla SedláčKovÁ ${ }^{1}$
}

\begin{tabular}{|l|l|}
\hline \multicolumn{1}{|c|}{ datum vzniku recenze: } & 21.12. 2020 \\
\hline 1.1 název nástroje: & Barevný test cesty pro děti \\
\hline \multicolumn{1}{|c|}{ zkrácený název: } & BTC \\
\hline 1.2 původní název: & \\
\hline 1.4 autoři původního testu: & Vladěna Šnoblochová, Lenka Krejčová \\
\hline 1.3 autoři lokální adaptace: & \\
\hline 1.7 lokální distributor: & Propsyco \\
\hline $1.9 .1 / 1.9 .2$ datum vydání: & 2017 \\
\hline
\end{tabular}

\section{Obecné informace o metodě}

Barevný test cesty pro děti je screeningovou metodou určenou pro měření pozornosti dětí ve věku od 5 do 7 let. Podle autorek lze test využít také jako součást diagnostiky školní zralosti nebo k usuzování na úroveň schopnosti vizuálně prostorové orientace dítěte. Test se skládá ze sedmi úkolů s progresivním charakterem. Úkolem probanda je spojovat poloviny koleček se stejnou barvou či vzorem tak, aby na sebe navazovaly. Obtížnost úkolů postupně roste, zvyšuje se počet podnětů a vzdálenost souvisejících podnětů.

Test je administrován individuálně ve formátu tužka-papír. Dítě je během administrace motivováno k tomu, aby pracovalo co nejrychleji, protože skórem testu je součet časů potřebných $\mathrm{k}$ vyplnění všech sedmi úkolů. Rychlejší výkon při zachované správnosti vyplnění značí lepší pozornost. Pro kvalitativní zhodnocení výkonu je vhodné zaznamenávat také počet chyb v jednotlivých úkolech, ale interpretace tohoto údaje není v testu zahrnuta. Administrace i vyhodnocení testu jsou rychlé, celkově zaberou cca 20 minut. Kvalifikační požadavky nejsou v manuálu uvedeny. Vydavatel uvádí, že podmínkou používání nástroje je licence B (absolventi bakalářského stupně psychologie a specialisté z příbuzných oborů).

\footnotetext{
${ }^{1}$ Katedra psychologie, Fakulta sociálních studií MU, Joštova 10, 60200 Brno
} 
Barevný test cesty pro děti vychází z široce užívané screeningové neuropsychologické metody pro dospělé Test cesty (Trail Making Test; dále TMT). Dětská verze tohoto testu je u nás rovněž standardizovaná, ale pouze pro děti ve věku 8 až 14 let (M. Preiss \& J. Preiss, 2006). BTC je nová metoda vyvinutá v České republice, která cílí na populaci dětí v předškolním a mladším školním věku. Standardizace byla provedena na vzorku 273 dětí ve věku 5 až 7 let. Manuál obsahuje normy rozdělené po šesti měsících věku (poslední interval 6;7;0-6;11;30 dní).

\section{Východiska testu}

Test cesty (TMT) je velmi rozšířená metoda v zahraničí i u nás, která umožňuje hodnotit pozornost, psychomotorické tempo, a také poukázat na možné poškození mozku. Tento test byl z počátku součástí armádních zkoušek a byl vytvořen R. Reitanem a D. Wolfsonem. První publikace TMT vyšla již v roce 1944 (citace podle M. Preiss \& J. Preiss, 2006). Ve verzi tohoto testu pro dospělé proband spojuje čárou bud' čísla (forma A), nebo kombinace čísel a písmen (forma B). Hodnocení výkonu probíhá na základě měřeného času potřebného ke splnění úkolů. Pro více informací o tomto testu bychom rády odkázaly na recenzi Motýla (2015) publikovanou v Testfóru.

K původní verzi TMT vytvořil R. Reitan v roce 1971 také dětskou verzi s menším množstvím bodů ke spojení (M. Preiss \& J. Preiss, 2006). Reitan se zaměřil na věkové rozmezí 9 až 14 let, přičemž v jeho studii nebyly zjištěny rozdíly mezi pohlavími. Podle studie Reitana a Wolfsona (2004) je test citlivý k neurologickým dysfunkcím i u dětí $\mathrm{v}$ daném věkovém rozmezí. $\mathrm{V}$ českém prostředí je standardizována jak verze pro dospělé, tak verze pro dětskou populaci, konkrétně pro děti od 8 do 14 let (M. Preiss \& J. Preiss, 2006). Na základě testu TMT byl dále vytvořen Color Trail Test a Children's Color Trail Test (dále CCTT), které cílily na odstranění kulturního a jazykového vlivu při neurologickém testování (Williams et al., 1995, citace podle Šnoblová \& Krejčová, 2017). V CCTT mají děti za úkol spojovat číslice od 1 do 15 v kolečkách se žlutým a růžovým pozadím. V prvním úkolu jsou lichá čísla umístěna v růžových kolečkách, sudá v kolečkách se žlutým pozadím, přičemž dítě spojuje čísla vzestupně. Ve druhém úkolu jsou př́itomna všechna čísla od 1 do 15 dvakrát a dítě má spojovat čísla vzestupně při současném střídání žlutého a růžového pozadí. CCTT je určen pro děti od 8 do 16 let. Alternativu TMT pro děti předškolního věku (3-5 let) tvoří Trails-P (Espy \& Cwik, 2004), kde jsou dětem předkládány barevné obrázky psů. Děti mají za úkol spojovat podle velikosti členy psí rodiny, kosti a kombinace psů a kostí. Tento test slouží pravděpodobně pouze pro výzkumné účely.

Úvodní kapitola manuálu se věnuje představení vývojových aspektů předškolních dětí, vývoji pozornosti $\mathrm{v}$ tomto období a příbuzným metodám TMT. V předškolním věku dochází k dramatickému vývoji kognitivních funkcí podílejících se na výkonu pozornosti. Významnou roli hrají exekutivní funkce. Dochází k rozvoji autoregulačního systému, schopnosti selektivně zaměřovat pozornost a dělit ji mezi více podnětů (Šnoblová \& Krejčová, 2017). Kognitivní úroveň dětí mezi 3. a 5. rokem se výrazně liší, a navíc může 
být ovlivněna různou podnětností prostředí (Anderson \& Reidy, 2012). Z toho důvodu vnímáme jako výhodu nového testu BTC, že se zaměřuje až na děti ve věku od 5 let. $V$ České republice je v tomto období zavedené povinné předškolní vzdělávání, což může přispět k částečnému srovnání kognitivní úrovně.

Šnoblová a Krejčová (2017) uvádí, že se vývojové aspekty snažily reflektovat při vývoji nástroje BTC. $V$ testu se dítě musí zaměřit na větší množství podnětů zároveň a musí flexibilně volit pouze některé z podnětů, které jsou v dané chvíli významné (selektivita) a naopak ignorovat distraktory (inhibice). Včasné zachycení obtíží může vést k návrhu vhodné intervence u dětí, a tím předejít souvisejícím problémům ve školním výkonu. Jelikož v ČR před vznikem BTC neexistovala metoda, která by se samostatně zaměřovala na rychlé zhodnocení pozornosti dětí mladších osmi let, je vytvoření této metody dle našeho názoru velkým př́nosem. Zároveň byly zjištěny rozdíly v normách $\mathrm{k}$ testu TMT v různých státech (Fernández \& Marcopulos, 2008), proto považujeme za velkou výhodu, že BTC vznikal př́mo v českém prostředí a jsou k dispozici české normy.

V teoretickém úvodu by mohly být prezentované informace lépe propojovány s konkrétním využitím při vývoji testu. Vývoj pozornosti a dalších kognitivních funkcí, které se k ní vážou, jsou vzhledem k metodě přiléhavé, ale bohužel zůstává nejasné, jak přesně se tato teorie promítla do vývoje metody a zejména podnětového materiálu. Stejný dojem budí část představující př́íbuzné nástroje.

\section{Administrace a skórování}

Manuál věnuje dostatečnou pozornost administraci i skórování. Administrace je prováděna individuálně za př́ítomnosti administrátora formou tužka-papír. Pro každou administraci je třeba testový sešit, záznamový arch, tužka a měřič času/stopky. Jak bylo řečeno, test se skládá ze sedmi úkolů progresivního charakteru. V testu má dítě spojit od pěti bodů v prvním a druhém úkolu až po 25 bodů v posledním úkolu.

Administraci je doporučeno provádět v klidném prostředí s minimem okolních rušivých vlivů, při dobrých světelných podmínkách a po navázání přiměřeného kontaktu s dítětem. Vzhledem k podobě testu je třeba se dopředu ujistit, že dítě rozlišuje barvy a rozumí instrukci. Postup je dítěti vysvětlován na ukázkové úloze a následně se jeho porozumění ověřuje na příkladové úloze. Tyto dvě úlohy jsou pouze cvičné a nezapočítávají se do výsledného skóre. Během administrace má být dítě motivováno k tomu, aby pracovalo co nejrychleji. Administrátor měří a zaznamenává čas potřebný $\mathrm{k}$ vyřešení jednotlivých úkolů. Čas se začíná měřit v momentě, kdy dítě začne kreslit tužkou. Dále je doporučeno zaznamenávat počet chyb ke kvalitativnímu hodnocení, nicméně interpretace není $\mathrm{v}$ manuálu uvedena. $\mathrm{V}$ př́padě chybování je dítě upozorněno, vráceno zpět k poslednímu správnému bodu a je pobídnuto zkusit to jinak. Měření času se nepozastavuje. Hrubý skór testu je součtem naměřených časů potřebných k vyřešení jednotlivých úkolů. Tento skór je následně pomocí normalizačních tabulek pro příslušný věk převeden na percentily. $\mathrm{V}$ tabulkách jsou uvedeny hodnoty každého pátého percentilu $(5,10,15, \ldots, 95)$. 
Test je krátký, umožňuje poměrně rychlou administraci i následné vyhodnocení. Administrace trvá přibližně 15 minut a vyhodnocení kolem 5-10 minut. Čas př́pravy byl odhadnut na 1 minutu. Dobu potřebnou k vyhotovení a poskytnutí zpětné vazby si netroufáme odhadovat, protože $\mathrm{v}$ manuálu není dostatek informací $\mathrm{k}$ jejímu doporučenému obsahu či formátu.

\section{Technické parametry}

Normy byly vytvořeny na standardizačním vzorku 273 dětí ve věku od 5 do 7 let. Při standardizaci byl zjišt’ován přesný věk probandů (roky, měsíce, dny), aby mohly být následně vytvořeny normy pro skupiny vždy po šesti měsících věku. Normy byly vytvořeny pro čtyři věkové kategorie $(5 ; 0 ; 0-5 ; 6 ; 30,5 ; 7 ; 0-5 ; 11 ; 30,6 ; 0 ; 0-6 ; 6 ; 30$ a 6;7;06;11;30). Zastoupení dětí bylo ve všech skupinách podobné. Normy jsou společné pro dívky a chlapce, v manuálu jsme však nenašly informace o kontrole vlivu pohlaví. Tvorba a standardizace metody proběhly $v$ rámci diplomové práce jedné ze spoluautorek (Šnoblová, 2017), pod vedením Lenky Krejčové. Tato diplomová práce je volně dostupná na internetu.

Sběr dat probíhal v mateřských a základních školách v deseti městech a obcích z různých krajů České republiky. Autorky se snažily zajistit rovnoměrné zastoupení pohlaví a respektovat populační zastoupení různých velikostí bydliště. Ve standardizačním vzorku bylo nakonec oproti obecnému populačnímu trendu více dětí z malých obcí, ale následná analýza ukázala, že by velikost bydliště neměla mít na výkon dětí vliv. Ačkoliv se autorky snažily získat vzorek, který dobře odpovídá uvažované populaci, nejedná se o reprezentativní vzorek, ale spíše o nahodilý kvótní výběr.

Manuál věnuje adekvátní pozornost validitě a reliabilitě. K ověření validity autorky zvolily konvergentní přístup. Jsou zde poskytnuty Pearsonovy koeficienty korelace BTC se skóry dalších podobně zaměřených testů - CAS2 (Plánovaná spojení), WJ-IV (Vybírání párů), IDS (Selektivní pozornost) - které se pohybují v rozmezí 0,282 až 0,664 . Subtest Plánovaná spojení (CAS2) je formátu BTC nejpodobnější a také s ním koreluje nejsilněji. Další dva subtesty nezahrnují časovou komponentu a korelují spíše slabě.

Další zdroje důkazů o validitě bohužel nejsou v manuálu poskytnuty a nenašly jsme ani informace o tom, že by byly předmětem dalšího výzkumu. Domníváme se, že data získaná pro standardizační studii v sobě nesou více informace, než autorky prezentují. V sekci o validitě metody např́klad chybí ověření vnitřní struktury testu pomocí faktorové analýzy. Na základě přiložené tabulky interkorelací jednotlivých úkolů je však možné faktorovou strukturu proměnných ověřit, proto jsme se rozhodly (ve spolupráci s konzultujícím editorem recenze, Hynkem Cíglerem) tento důkaz validity doplnit alespoň pro účely této recenze. Pomocí konfirmační faktorové analýzy s odhadem metodou maximální věrohodnosti byl ověřen jednofaktorový model, kdy časy každé proměnné byly syceny jednou společnou latentní proměnnou (rychlost práce). Povolení pozitivní reziduální kovariance mezi dvěma posledními úkoly vedlo k dobré shodě modelu s daty $(C F I=0,985$; $T L I=0,976 ; S R M R=0,026 ; R M S E A=0,076 ; 90 \% C I[0,044 ; 0,108])$. Vyšší souvislost 
posledních dvou úkolů dává z teoretického hlediska smysl. Tyto úkoly obsahují větší počet složitějších podnětů, takže je potřeba více času $\mathrm{k}$ jejich splnění a dlouhé úlohy jsou zpracovávány jinými kognitivními systémy. Může však jít rovněž o efekt únavy či jiný proces. U proměnné počet chyb se nepodařilo ověřit jednofaktorovou strukturu a více informací nám neposkytla ani explorační faktorová analýza. Tato proměnná však slouží pouze ke kvalitativnímu zhodnocení a nezapočítává se do celkového skóre.

Reliabilita byla ověřována z hlediska stability v čase. S odstupem 20 až 40 dní bylo u 24 dětí provedeno opakované měření. Hodnota test-retestové reliability byla $r=0,68$, což podle autorek značí silnou závislost mezi jednotlivými měřeními. My bychom ji hodnotily jako adekvátní a zdůraznily bychom limit malého vzorku. Pomocí neparametrického Wilcoxonova párového testu a testu znaménkového byly zjištěny signifikantní rozdíly mezi prvním a druhým měřením. Došlo ke zrychlení průměrného času ze 193s na 181s, pravděpodobně díky zácviku či předchozí zkušenosti s testovou situací. Počet chyb byl nezávislý na opakovaných měření a hodnota test-retestové reliability počtu chyb byla $\mathrm{r}=0,48$. Tyto informace je třeba brát v potaz při zvažování užití testu pro opakovaná měření. Měsíční odstup je možná př́liš krátký interval, a proto by budoucí výzkum mohl zkusit ověřit, zda tento efekt přetrvává i po delší době.

Autorky usuzují na vysokou vnitřní konzistenci z toho, že děti, které odpovídaly rychleji v lehčích úkolech, byly rychlejší i v těžších úkolech (a naopak). Odkazují se na tabulku interkorelací mezi jednotlivými úkoly, která je uvedena v přílohách. Na základě této tabulky jsme vypočetly standardizovanou Cronbachovu alfu, čímž jsme se ujistily o vysoké vnitřní konzistenci o hodnotě $0,92 \mathrm{v}$ př́ípadě rychlosti plnění úkolů a uspokojivé reliabilitě $0,79 \mathrm{v}$ případě chybovosti. Přestože je možné koeficienty z uvedených informací dopočítat, jejich neuvedení v manuálu vnímáme jako nedostatek. Uvedená hodnota reliability se vztahuje na celý vzorek. Vzhledem k předpokládanému vlivu věku na výkon pozornosti může být tento odhad nadhodnocený oproti hodnotám reliability uvnitř jednotlivých kohort, které není možné z dostupných dat dopočítat.

\section{Komentár̆}

Screeningová metoda Barevný test cesty pro děti je určena pro děti od 5 do 7 let, v čemž spatřujeme hlavní silnou stránku této metody. $\mathrm{V}$ českém prostředí nebyl k dispozici podobný test, který by se zaměřoval na rychlé zhodnocení pozornosti dětí v této věkové skupině. BTC je dle našeho názoru podobný alternativě TMT - Children's Color Trail Test, který bohužel není dostupný v ČR. V obou testech mají děti za úkol spojovat barevná kolečka, u obou testů je skórem čas, dítě je podporováno k co nejrychlejší práci po absolvovaném zácviku, počet chyb je zaznamenáván, avšak není skórován. Testy však cílí na jinou věkovou populaci. CCTT je určen až pro děti od 8 let, protože je nutná znalost číslic. BTC je založen na spojování koleček pouze na základě různých barev a vzorů, bez prrítomnosti číslic. Z našeho pohledu však může být podnětový materiál BTC paradoxně náročnější (zejména poslední úkoly) a mohl by mít potenciál i pro standardizaci pro starší populaci. 
Výhodu metody spatřujeme v tom, že vznikala př́ímo v prostředí ČR a díky standardizaci vznikly normy na českém vzorku dětí, i když ne zcela reprezentativním. Tyto normy jsou dostupné v manuálu. Manuál metody je přehledný, díky čemuž je umožněna dobrá orientace v textu. Součástí manuálu jsou podrobné informace k administraci, včetně znění přesné instrukce pro administraci. Informace poskytnuté $\mathrm{k}$ validitě a reliabilitě hodnotíme jako adekvátní, nicméně k těmto sekcím by dle našeho názoru bylo vhodné doplnit více důkazů.

Slabou stránku metody spatřujeme v některých chybějících údajích, které bychom pro komplexnější pohled ocenily. V manuálu nejsou explicitně uvedeny údaje o tom, v kterých všech oblastech lze metodu využít. Obecně nám zde chybí část věnující se samostatně záměru testu. Ten lze odvozovat z poskytnutých informací např́ič manuálem, nicméně tato oblast by si zasloužila samostatný ucelený prostor. Stejně tak chybí informace k vlastnímu vývoji úkolů $\mathrm{v}$ testu. $\mathrm{K}$ vývoji testu jsou poskytnuty pouze informace o původním testu TMT a jeho alternativách (např. Children's Color Trail Test), ze kterých BTC vychází. Prezentované informace by mohly být lépe propojovány s jejich konkrétní aplikací (viz výše). Při administraci je doporučeno kromě času zaznamenávat také počet chyb k následnému kvalitativnímu posouzení, ale bližší informace k jejich interpretaci nejsou uvedeny. Za problémové považujeme, že autorky nezvažují chybu měření a její zapojení do intepretace výsledků testu. Není uveden ani koeficient vnitřní konzistence testu. Autorky v manuálu usuzují na vnitřní konzistenci testu na základě tabulky interkorelací položek, ze které lze dopočítat koeficient pro celý vzorek, ale ne pro jednotlivé kohorty.

I přes uvedené nedostatky hodnotíme Barevný test cesty pro děti jako kvalitní nástroj pro screeningové vyšetření pozornosti dětí od 5 do 7 let, který umožňuje rychlé prvotní posouzení výkonu pozornosti těchto dětí. Před administrací testu je nutné pečlivě prostudovat manuál a instrukce $\mathrm{k}$ administraci, aby nedošlo ke zkreslení výsledku administrátorem. Kvalifikační požadavky nejsou uvedeny. Co se týče profesionální kvalifikace, vydavatel uvádí, že podmínkou používání nástroje je licence $\mathrm{B}$, tj. absolventi bakalářského stupně psychologie a specialisté z př́ibuzných oborů. Nastavené požadavky dle našeho názoru odpovídají náročnosti kladené na administrátora.

Tento test je dostupný na stránkách vydavatele Propsyco, s.r.o. za pořizovací cenu 854,70 Kč včetně DPH. Vydavatel nás informoval, že jedno kompletní balení metody obsahuje příručku a 30 ks testových sešitů. K administraci je třeba pro každé dítě vlastní testový sešit s úkoly a záznamový arch (dostupný v přílohách příručky). Za počáteční náklady je možné vyšetřit 30 dětí. Na stránkách vydavatele lze dokoupit testové sešity (435 Kč včetně DPH, 30 ks).

\section{Shrnutí}

Barevný test cesty pro děti je podle nás vhodným nástrojem pro zamýšlené účely, tj. screeningové vyšetření pozornosti u dětí ve věku od 5 do 7 let. Nízký skór v testu nelze s aktuálními normami nijak blíže interpretovat a měl by tedy sloužit pouze jako doporučení 
pro komplexnější diagnostiku pozornosti a exekutivních funkcí. Administrace je nenáročná a instrukce pro administrátora poskytnuté v manuálu jsou z našeho pohledu přehledné a dostačující. Skórování testu je do velké míry nezávislé na osobě administrátora, ale jelikož v manuálu chybí informace k doporučenému obsahu či formátu zpětné vazby, administrátoři by měli skutečně dbát na to, že výsledek testu je spíše orientačním ukazatelem. S vědomím výše uvedených omezení je možné metodu použít způsobem, který uvádí vydavatel metody.

\section{Zdroje}

Anderson, P. J., \& Reidy, N. (2012). Assessing executive functions in preschoolers. Neuropsychology Review, 22(4), 345-360. https://doi.org/10.1007/s11065-012-9220-3

Espy, K. A., \& Cwik, M. F. (2004). The development of a Trial Making Test in young children: The TRAILS-P, The Clinical Neuropsychologist, 18(3), 411-422.

https://doi.org/10.1080/138540409052416

Fernández, A. L., \& Marcopulos, B. A. (2008). A comparison of normative data for the Trail Making Test from several countries: equivalence of norms and considerations for interpretation. Scandinavian Journal of Psychology, 49(3), 239-246.

https://doi.org/10.1111/j.1467-9450.2008.00637.x

Motýl, J. (2015). Test cesty: Recenze metody. Testfórum, 4(6), 47-52.

https://doi.org/10.5817/TF2015-6-85

Preiss, M., \& Preiss, J. (2006). Test cesty. Psychodiagnostika.

Reitan, R. M., \& Wolfson, M. (2004). The Trail Making Test as an initial screening procedur efor neuropsychological impairment in older children. Archives of Clinical Neuropsychology, 19(2), 281-288. https://doi.org/10.1016/S0887-6177(03)00042-8

Šnoblová, V., \& Krejčová, L. (2017). Barevný test cesty pro děti. Propsyco.

Šnoblová, V. (2017). Diagnostika pozornosti u dětí v předškolním a mladším školním věku. [Nepublikovaná diplomová práce]. Univerzita Karlova. 


\author{
EFPA \\ STANDING COMMITTEE ON \\ TESTS AND TESTING (SCTT)
}

Příloha ke Zprávě předsedy, 2005

MODEL RECENZE PODLE EFPA PRO POPIS

A HODNOCENÍ PSYCHOLOGICKÝCH TESTŮ

FORMULÁŘ RECENZE TESTU A POZNÁMKY PRO RECENZENTY

Verze 3.42

Lokální úprava pro časopis Testforum

ISSN 1805-9147 


\section{MODEL RECENZE PODLE EFPA PRO POPIS \\ A HODNOCENÍ PSYCHOLOGICKÝCH TESTŮ \\ FORMULÁŘ RECENZE TESTU A POZNÁMKY PRO \\ RECENZENTY ${ }^{1}$}

Toto je lokální úprava dokumentu pro účely publikace v časopise Testfórum.

Originální český překlad je k dispozici na stránkách EFPA

(www.efpa.eu/download/505cd9db4144ecb16174087909c9cd6d).

Původní verzi sestavil a uspořádal Dave Bartram

Doplnili a revidovali Patricia Lindley, Dave Bartram a Natalie Kennedy v dubnu $2004^{2}$

Současná verze 3.42: květen 2005

Český překlad: Tomáš Urbánek

Od uživatelů tohoto dokumentu a jeho obsahu žádá EFPA, aby uznali tento zdroj prostřednictvím následujícího textu:

"Kritéria pro recenzi testu podle EFPA do značné míry vychází z formy a obsahu kritérií pro recenze testů Britské psychologické společnosti (BPS) a kritérií vytvořených Komisí pro testové záležitosti (COTAN) Holandské asociace psychologů (NIP). Dave Bartram a Patricia Lindley pưvodně vyvinuli kritéria BPS a recenzní procedury pro UK Employment Service a později rozšírili jejich používání pro celou BPS. Arne Evers připravil k vydání nizozemský system posuzování kvality testů.

EFPA je vděčná BPS a NIP za svolení použítjejich kritéria jako základ pro vytvoření evropského modelu. EFPA je také vděčná Davu Bartramovi, Arnu Eversovi a Patricii Lindley za jejich přispění $k$ vývoji tohoto modelu. Veškerá intelektuální vlastnická práva původních kritérií podle BPS a NIP jsou nadále uznávána a náleží těmto orgánům."

\footnotetext{
1 Tento dokument byl vytvořen z několika zdrojů, včetně Hodnotícího formuláře pro recenzi testu používaného v BPS (NPAL a Řídící komise pro testové standardy při BPS - Steering Committee on Test Standards), Španělského dotazníku pro hodnocení psychometrických testů (Španělská psychologická asociace) a Systému pro posuzování kvality testu (Komise pro testování Holandské asociace psychologů). Některé části byly adaptovány se svolením z dokumentu: BPS Books Reviews of Level B Assessment Instruments for use in Occupational Assessment, Notes for Reviewers: Version 3.1. December 1998: Copyright (C) NPAL, 1989, 1993, 1998.

2 Současná verze je spojením dvou oddělených dokumentů (Formuláře recenze a Poznámek pro recenzenty). Obsah byl navíc uspořádán a doplněn na základě jeho používání recenzenty online testů v BPS.
} 


\section{Č́st 1:}

\section{Popis nástroje: Obecné informace a klasifikace}

\begin{tabular}{|c|c|c|}
\hline \multicolumn{3}{|c|}{ FPA 3.2 reference } \\
\hline & Recenzent 1: & Bc. Simona Galbavá \\
\hline & Recenzent 2: & Bc. Pavla Sedláčková \\
\hline & Konzultující editor: & Mgr. Hynek Cígler, Ph.D. \\
\hline & Vedoucí editor: & Mgr. Jaroslav Gottfried \\
\hline & $\begin{array}{l}\text { Vedoucí editor aktualizace: } \\
\text { (pouze v př́padě aktualizací) }\end{array}$ & \\
\hline & $\begin{array}{l}\text { Editor aktualizace: } \\
\text { (pouze v př́padě aktualizací) }\end{array}$ & \\
\hline & Datum vzniku této recenze: & 21. 12.2020 \\
\hline 1.1 & Název nástroje (lokální verze): & Barevný test cesty pro děti \\
\hline & Zkrácená verze názvu testu: & BTC \\
\hline 1.2 & $\begin{array}{l}\text { Původní název testu (pokud je lokální } \\
\text { verze adaptací): }\end{array}$ & \\
\hline 1.4 & Autoři původního testu: & Vladěna Šnoblová, Lenka Krejčová \\
\hline 1.3 & Autoři lokální adaptace: & \\
\hline 1.7 & Lokální distributor/vydavatel testu: & Propsyco, s.r.o. \\
\hline 1.8 & $\begin{array}{l}\text { Vydavatel původní verze testu (pokud je } \\
\text { jiný než současný distributor/vydavatel): }\end{array}$ & \\
\hline 1.9 .1 & Datum vydání současné revize/vydání: & \\
\hline 1.9 .2 & $\begin{array}{l}\text { Datum vydání adaptace pro lokální } \\
\text { užívání: }\end{array}$ & \\
\hline 1.9 .3 & Datum vydání původního testu: & 2017 \\
\hline
\end{tabular}




\section{Obecný popis nástroje}

Barevný test cesty pro děti je screeningovou metodou určenou pro měření pozornosti dětí ve věku od 5 do 7 let. Podle autorek lze test využít také jako součást diagnostiky školní zralosti nebo k usuzování na vizuálně prostorovou orientaci dítěte. Test se skládá ze sedmi úkolů s progresivním charakterem. Úkolem probanda je spojovat poloviny koleček se stejnou barvou či vzorem tak, aby na sebe navazovaly. Obtížnost úkolů postupně roste, zvyšuje se počet podnětů a vzdálenost souvisejících podnětů.

Test je administrován individuálně ve formátu tužka-papír. Dítě je během administrace motivováno k tomu, aby pracovalo co nejrychleji, protože skórem testu je součet časů potřebných k vyplnění všech sedmi úkolů. Rychlejší výkon značí lepší pozornost. Pro kvalitativní zhodnocení výkonu je vhodné zaznamenávat také počet chyb $\mathrm{v}$ jednotlivých úkolech, ale interpretace tohoto údaje není $\mathrm{v}$ testu zahrnuta. Administrace i vyhodnocení testu jsou rychlé, celkově zaberou cca 20 minut. Kvalifikační požadavky nejsou v manuálu uvedeny. Vydavatel uvádí, že podmínkou používání nástroje je licence B (absolventi bakalářského stupně psychologie a specialisté z př́ibuzných oborů).

Barevný test cesty pro děti vychází z široce užívané screeningové neuropsychologické metody pro dospělé Test cesty (Trail Making Test; dále TMT). Dětská verze tohoto testu je u nás rovněž standardizovaná, ale pouze pro děti ve věku 8 až 14 let (Preiss, \& Preiss, 2006). BTC je nová metoda vyvinutá v České republice, která cílí na populaci dětí v předškolním a mladším školní věku. Standardizace byla provedena na vzorku 273 dětí ve věku 5 až 7 let. Manuál obsahuje normy rozdělené po šesti měsících věku (poslední interval 6;7;0-6;11;30 dní).

\section{Č́st 2:}

Klasifikace

\begin{tabular}{|c|c|c|}
\hline 1.10 .1 & Obsahová doména & 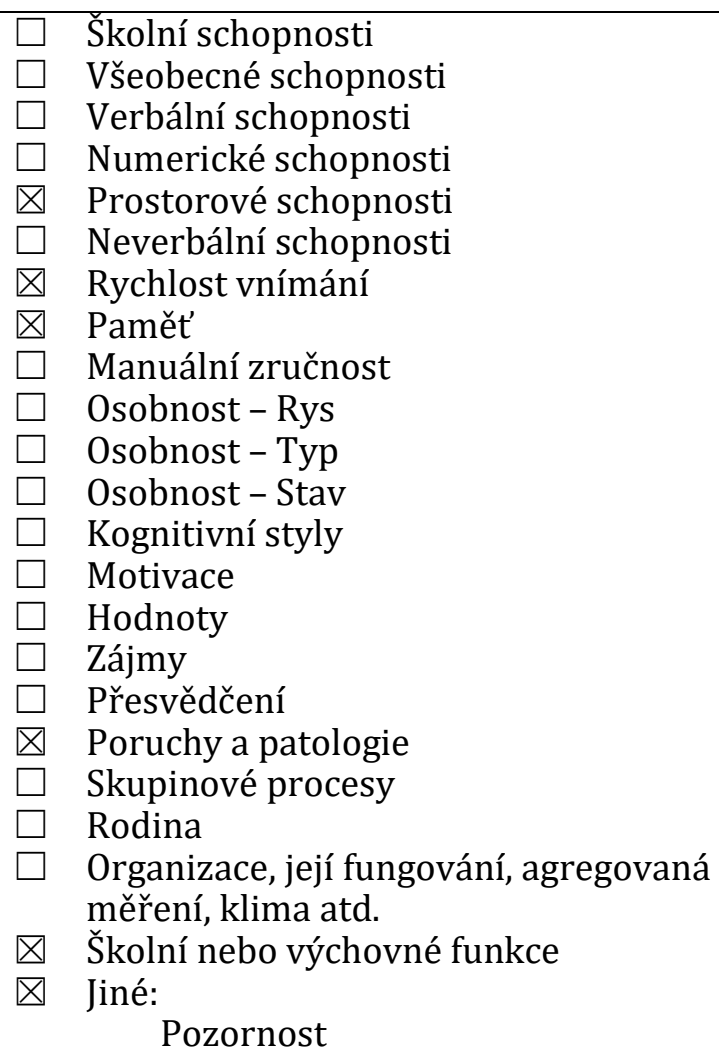 \\
\hline
\end{tabular}




\begin{tabular}{|c|c|c|}
\hline 1.10 .2 & $\begin{array}{l}\text { Zamýšlená(é) nebo hlavní oblast(i) } \\
\text { použití. }\end{array}$ & $\begin{array}{ll}\bigotimes & \text { Klinická psychologie } \\
\bigotimes & \text { Neuropsychologie } \\
\square & \text { Forenzní psychologie } \\
\bigotimes & \text { Psychologie výchovy a vzdělávání } \\
\square & \text { Psychologie práce a personalistika } \\
\square & \text { Poradenství, doporučení, vedení a volba } \\
& \text { povolání } \\
\square & \text { Psychologie zdraví, životní styl a životní } \\
& \text { spokojenost } \\
\square & \text { Sporty a volný čas } \\
\square & \text { Jiné: }\end{array}$ \\
\hline 1.10 .3 & $\begin{array}{l}\text { Zamýšlený způsob použití } \\
\text { (podmínky, za jakých byl nástroj } \\
\text { standardizován a validizován) }\end{array}$ & $\begin{array}{l}\text { Nesupervidovaná administrace bez } \\
\text { kontroly nad identitou respondenta a bez } \\
\text { úplné kontroly nad podmínkami } \\
\text { administrace (např. volně přístupný test } \\
\text { na internetu, test dostupný ke koupi v } \\
\text { knihkupectví). } \\
\text { Kontrolovaný nesupervidovanou } \\
\text { administrcí. Kontrola nad podmínkami } \\
\text { (čas atd.) a určitá kontrola nad identitou } \\
\text { uživatele testu (např. testy } \\
\text { administrované přes internet, ale pouze } \\
\text { známým osobám - př́ístup omezený } \\
\text { heslem). } \\
\text { Supervidovaná a kontrolovaná } \\
\text { administrace. Administrace testu pod } \\
\text { kontrolou kvalifikovaného adminitrátora } \\
\text { nebo dohlížitele. } \\
\text { Řízená administrace. Administrace testu } \\
\text { prováděná pouze přes určená testovací } \\
\text { centra (např. programy hodnocení licencí } \\
\text { a certifikace). }\end{array}$ \\
\hline 1.10 .4 & $\begin{array}{l}\text { Popis populací, pro které je test } \\
\text { určen: }\end{array}$ & Děti ve věku od 5 do 7 let. \\
\hline 1.10 .5 & $\begin{array}{l}\text { Počet škál a krátký popis } \\
\text { proměnné nebo proměnných } \\
\text { měřených nástrojem }\end{array}$ & $\begin{array}{l}\text { Čas splnění úkolu: U každého úkolu je měřen } \\
\text { čas od chvíle, kdy dítě začne podněty spojovat } \\
\text { až po dosažení posledního podnětu. Rychlejší } \\
\text { výkon značí lepší pozornost. } \\
\text { Hrubým skórem testu je součet všech sedmi } \\
\text { časủ plnění úkolu, který je následně převeden } \\
\text { na percentily. } \\
\text { Počet chyb: Při administraci testu je } \\
\text { doporučeno zaznamenávat také počet chyb } \\
\text { pro kvalitativní zhodnocení výkonu. } \\
\text { V případě chyby administrátor dítě upozorní } \\
\text { a vede k nápravě. Počet chyb skórován není. }\end{array}$ \\
\hline
\end{tabular}




\begin{tabular}{|c|c|c|}
\hline 1.11 & Formát položek & $\begin{array}{l}\square \quad \text { Otevřený } \\
\square \quad \text { Mnohonásobná volba, alternativy na } \\
\text { stejné škále } \\
\square \quad \text { Bipolární adjektiva } \\
\square \quad \text { Likertovy ratingy (škály) } \\
\square \quad \text { Nucená volba, alternativy na smíšených } \\
\text { škálách (ipsativní) - vysvětlení viz } \\
\text { Poznámky } \\
\square \quad \text { Mnohonásobná volba, alternativy na } \\
\text { smíšených škálách (ipsativní) - } \\
\text { vysvětlení viz Poznámky } \\
\square \quad \text { Sady párủ adjektiv (sémantický } \\
\text { diferenciál), smíšené škály (ipsativní) } \\
\text { Jiné: } \\
\text { Test má položky úkolového formátu. } \\
\text { Proband spojuje body na základě } \\
\text { instrukce, přičemž je měřen čas } \\
\text { potřebný ke splnění úkolu a } \\
\text { zaznamenává se počet chyb. }\end{array}$ \\
\hline 1.12 & Počet položek testu: & $\begin{array}{l}\text { Test se skládá ze } 7 \text { úkolů progresivního } \\
\text { charakteru. } V \text { prvních dvou úkolech je potřeba } \\
\text { spojit } 5 \text { bodů a v dalších postupně } 8,10,10,15 \\
\text { a } 25 \text { bodů. }\end{array}$ \\
\hline 1.13 & Způsob(y) administrace: & $\begin{array}{ll}\bigotimes & \text { Interaktivní individuální administrace } \\
\square & \text { Supervidovaná skupinová administrace } \\
\square & \text { Počítačová lokálně nainstalovaná } \\
\text { aplikace - pod supervizí/dohledem } \\
\square & \text { Počítačová aplikace na webu - pod } \\
\text { supervizí/dohledem } \\
\square \\
\text { Počítačová lokálně nainstalovaná } \\
\text { aplikace - bez supervise/testování sebe } \\
\square \\
\text { Počítačová aplikace na webu - bez } \\
\text { supervize/testování sebe } \\
\square \text { Jiné: }\end{array}$ \\
\hline 1.14 & Způsob odpovídání: & $\begin{array}{ll} & \text { Ústní rozhovor } \\
\bigotimes & \text { Papír a tužka } \\
\square & \text { Manuální operace } \\
\square & \text { Na počítači } \\
\bigotimes & \text { Jiné: } \\
& \text { Měřič času/stopky }\end{array}$ \\
\hline
\end{tabular}




\begin{tabular}{|c|c|c|c|}
\hline 1.15 & 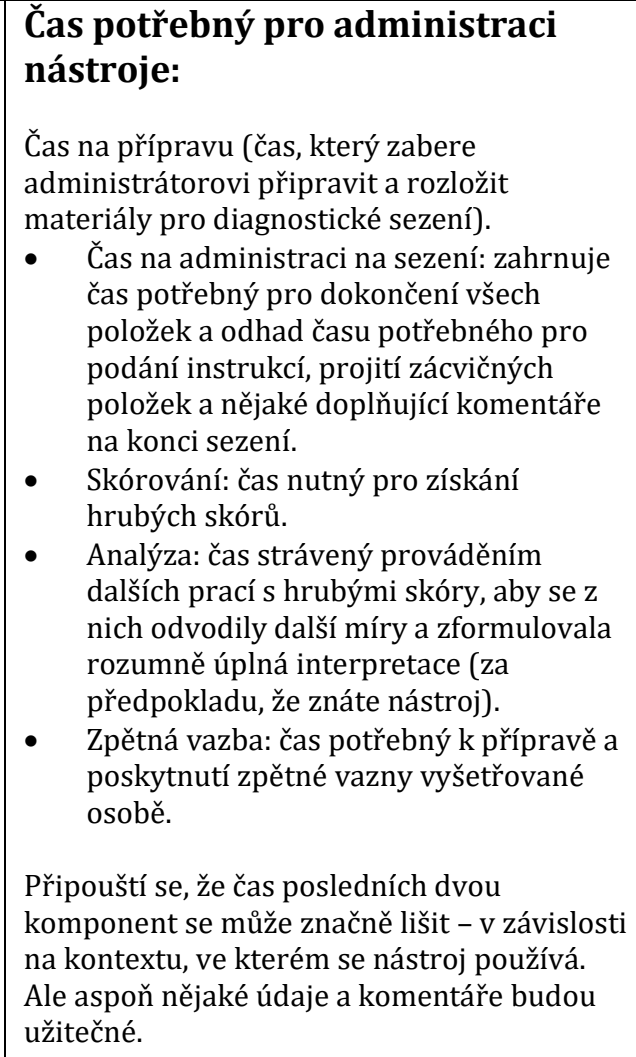 & $\begin{array}{l}\text { Příprava: } \\
\text { Administrace: } \\
\text { Skórování: } \\
\text { Analýza: } \\
\text { Zpětná vazba: } \\
\text { Autorky explici } \\
\text { zvlášt' pro skór } \\
\text { 5-10 minut k v } \\
\text { Uvedený čas jsr } \\
\text { s administrací } \\
\text { Čas př́pravy by } \\
\text { Informace k po } \\
\text { nejsou v manuá } \\
\text { tuto část ponec }\end{array}$ & $\begin{array}{l}1 \text { minuta } \\
15 \text { minut } \\
\text { 1-2 minuty } \\
\text { 4-8 minut } \\
\text { Není uvedeno. } \\
\text { tně neuvádí čas potřebný } \\
\text { ování a analýzu, uvádí } \\
\text { yhodnocení testu. } \\
\text { ne na základě zkušenosti } \\
\text { ozdělily mezi dílćí ćásti. } \\
\text { l rovněž odhadnut. } \\
\text { kytování zpětné vazby } \\
\text { lu uvedené, proto jsme } \\
\text { haly bez odhadu. }\end{array}$ \\
\hline 1.16 & $\begin{array}{l}\text { Jsou } k \text { dispozici různé formy } \\
\text { nástroje? }\end{array}$ & $\begin{array}{l}\text { Ne, alternativní } \\
\text { test cesty pro dè } \\
\text { jsou jiné testy ce } \\
\text { starší populaci. }\end{array}$ & $\begin{array}{l}\text { formy nástroje Barevný } \\
\text { ti neexistují. K dispozici } \\
\text { sty, avšak pouze pro }\end{array}$ \\
\hline
\end{tabular}

\section{Část 3:}

\section{Měření a skórování}

\begin{tabular}{|c|c|c|}
\hline 1.17 & Procedura skórování testu: & 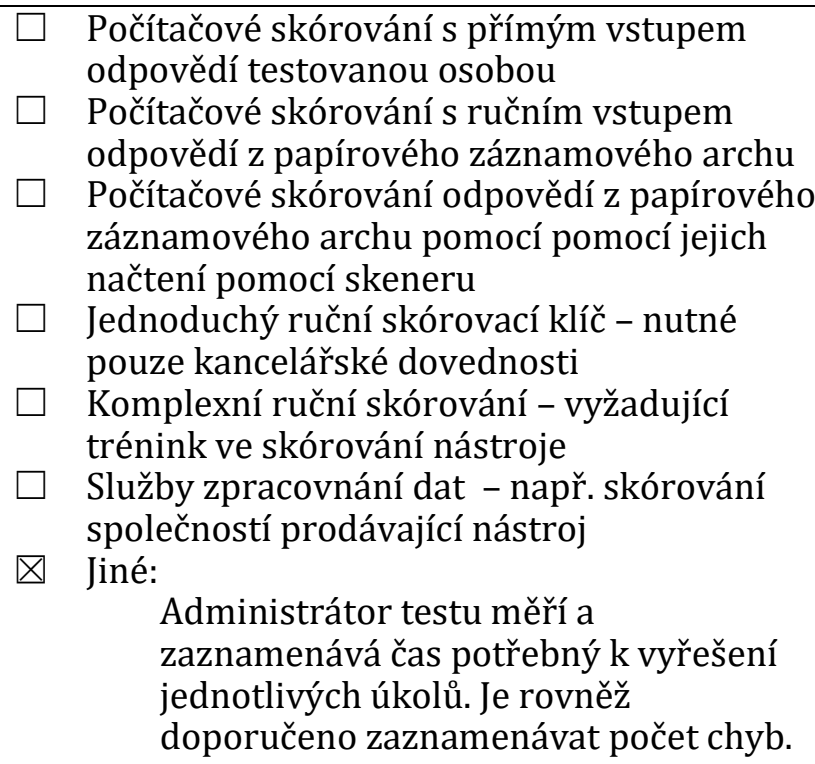 \\
\hline
\end{tabular}




\begin{tabular}{|c|c|c|}
\hline 1.18 & Skóry: & $\begin{array}{l}\text { Hrubý skór testu je součtem naměřených časů } \\
\text { potřebných k vyřešení jednotlivých úkolù. } \\
\text { Hrubý skór je následně pomocí normalizačních } \\
\text { tabulek pro př́slušný věk převeden na } \\
\text { percentily. V tabulkách jsou uvedeny hodnoty } \\
\text { každého pátého percentilu }(5,10,15, \ldots, 95) .\end{array}$ \\
\hline 1.19 & $\begin{array}{l}\text { Transformace skóru na standardní } \\
\text { skóry: }\end{array}$ & $\begin{array}{ll} & \text { Normalizovaná - skóry se získají použitím } \\
\text { normalizační tabulky } \\
\square \quad \text { Nenormalizovaná - skóry se získají lineární } \\
\text { transformací }\end{array}$ \\
\hline 1.20 & Použité škály & 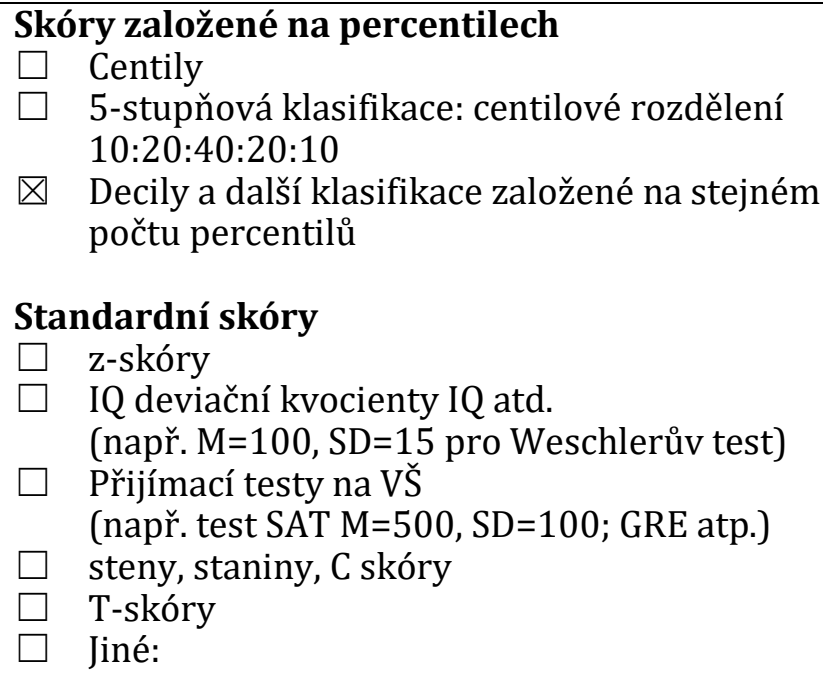 \\
\hline
\end{tabular}

\section{Část 4:}

\section{Počítačově generované zprávy}

Toto je čistě popisné. Hodnocení zpráv bude součástí části recenze nazvané Hodnocení.

\begin{tabular}{|l|l|ll|}
\hline 1.21 & $\begin{array}{l}\text { Jsou počítačově generované zprávy } \mathbf{k} \\
\text { dispozici s nástrojem? }\end{array}$ & $\square \quad$ Ano \\
& $\bigotimes \quad \mathrm{Ne}$ \\
\hline
\end{tabular}

\section{Č́st 5:}

\section{Nabídka, podmínky a náklady}

Tato část definuje, co vydavatel poskytne, komu, za jakých podmínek a za jaké ceny. Definuje podmínky kladené dodavatelem a týkající se toho, kdo smí a kdo nesmí získat materiál nástroje. Pokud jedna z možností neodpovídá podmínkám nabídky, doplňte popis relevantních podmínek. 


\begin{tabular}{|c|c|c|}
\hline 1.23 & $\begin{array}{l}\text { Dokumentace poskytovaná } \\
\text { distributorem jako součást } \\
\text { testového balíku }\end{array}$ & 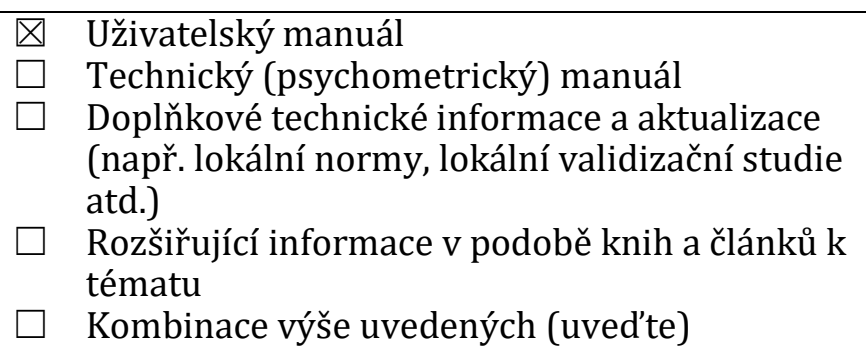 \\
\hline 1.24 & Metody publikace & $\begin{array}{ll} & \text { Papír } \\
\square & \text { PC - Diskety } \\
\square & \text { PC - CD/ROM } \\
\square & \text { Download z internetu } \\
\square & \text { Živý internet (nástroj pracuje v internetovém } \\
& \text { prohlížeči) } \\
\square & \text { Jiné: }\end{array}$ \\
\hline 1.25 .1 & $\begin{array}{l}\text { Počáteční náklady. } \\
\text { Cena kompletní sady materiálů (všechny manuály a } \\
\text { další material nutný k aspoň jedné zkušební } \\
\text { administraci). Kolik uchazečú lze vyšetřovat pomocí } \\
\text { materiálù získaných za počáteční náklady, kde tyto } \\
\text { náklady zahrnují materially pro opakované vyšetření. }\end{array}$ & $\begin{array}{l}\text { K datu 10. 1. } 2021 \text { je na webových stránkách } \\
\text { vydavatelství Propsyco test dostupný za cenu } \\
854,70 \text { Kč včetně DPH. Distributor uvažuje o úpravě } \\
\text { ceny na } 860 \text { Kč. Kompletní balení metody obsahuje } \\
\text { prŕručku a } 30 \text { ks testových sešitů. Záznamový arch } \\
\text { je dostupný v př́lohách př́ručky. Za počáteční } \\
\text { náklady lze vyšetřit } 30 \text { dětí. }\end{array}$ \\
\hline 1.25 .2 & Opakující se náklady: & $\begin{array}{l}\text { Při každé administraci je třeba spotřebovat testový } \\
\text { sešit a záznamový arch. Testové sešity je možné } \\
\text { dokoupit přes Propsyco, s. r. o. (435 Kč včetně DPH, } \\
30 \text { ks). Distributor uvažuje o nové ceně } 440 \text { Kč. } \\
\text { Záznamový arch je dostupný v příloze příručky. }\end{array}$ \\
\hline $\begin{array}{ll}1.26 .1 \\
\end{array}$ & $\begin{array}{l}\text { Ceny za zprávy generované } \\
\text { softwarem nainstalovaným } \\
\text { uživatelem: }\end{array}$ & \\
\hline 1.26 .2 & $\begin{array}{l}\text { Ceny za vyhotovení zprávy zaslené } \\
\text { prostřednictvím pošty/faxu: }\end{array}$ & \\
\hline 1.26 .3 & $\begin{array}{l}\text { Ceny za vyhotovení zprávy zaslené } \\
\text { prostřednictvím internetové služby: }\end{array}$ & \\
\hline 1.27 & $\begin{array}{l}\text { Ceny za další služby a zpracování } \\
\text { dat: opravy nebo vývoj } \\
\text { automatických zpráv: }\end{array}$ & \\
\hline 1.28 & 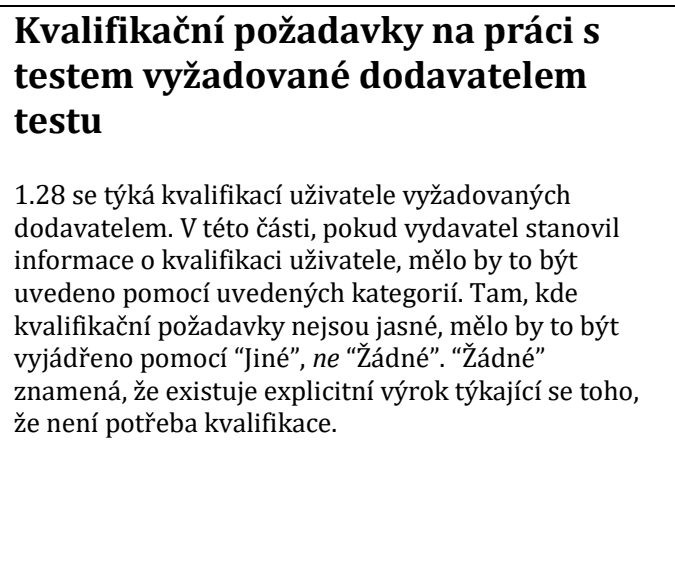 & $\begin{array}{l}\otimes \quad \text { Žádné } \\
\square \quad \text { Oprávnění (certifikát) pro specifický test } \\
\square \text { Oprávnění (certifikát) pro obecné výkonové } \\
\text { testy: i. e. míry maximálního výkonu ve } \\
\text { schopnostech } \\
\square \text { Potvrzení v testování obecných schopností a } \\
\text { dovedností: míry maximálního výkonu ve } \\
\text { vztahu k potenciálu k výkonu } \\
\square \text { Potvrzení v obecné diagnostice a diagnostice } \\
\text { osobnosti: míry typického chování, postojů a } \\
\text { preferencí } \\
\square \text { Jiné: }\end{array}$ \\
\hline
\end{tabular}




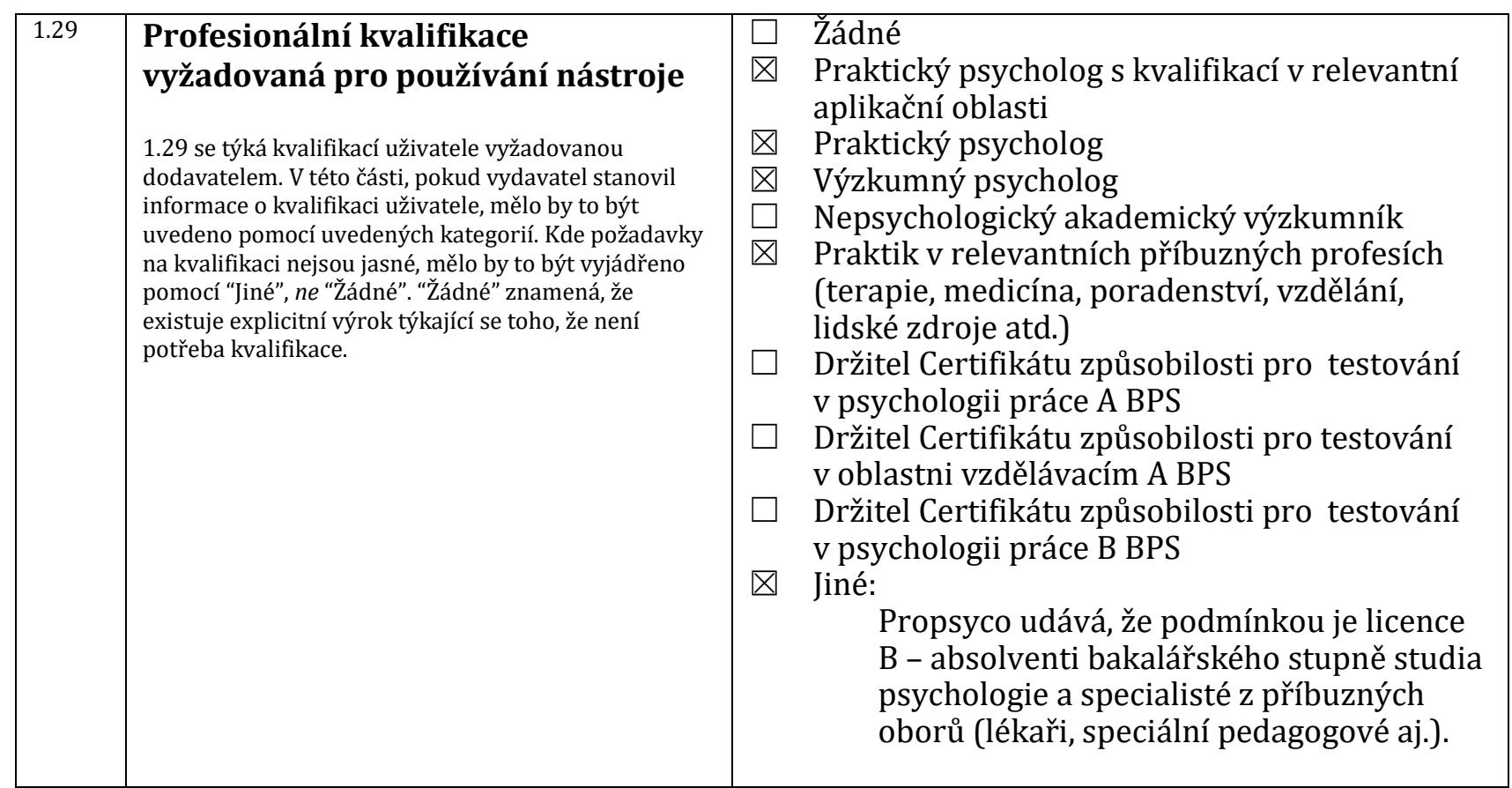

\section{Část 6:}

\section{Hodnocení testových materiálů}

V následujících částech jsou celková posouzení adekvátnosti informací týkajících se validity, reliability a norem zobrazeny automaticky tučně.

Jakýkoli nástroj $s$ jedním nebo více posouzeními 0 nebo 2 týkajícími se atributů považovaných za kritické pro bezpečné používání nástroje, by neměl být považován za nástroj, který splňuje minimální standardy.

\begin{tabular}{|c|c|c|c|}
\hline $\begin{array}{c}\text { Vstup na posuzovacím } \\
\text { formuláři }\end{array}$ & $\begin{array}{l}\text { Posouzení podle } \\
\text { standardů EFPA }\end{array}$ & $\begin{array}{c}\text { Reprezentace recenze } v \\
\mathrm{UK}\end{array}$ & Vysvětlení \\
\hline [n/a] & [n/a ] & [n/a ] & $\begin{array}{l}\text { Tento atribut není u tohoto } \\
\text { nástroje použitelný }\end{array}$ \\
\hline $\mathbf{0}$ & {$[-]$} & [None ] & $\begin{array}{c}\text { Není možné posoudit jako } \\
\text { ne nebo nedostatek } \\
\text { poskytnutých informací }\end{array}$ \\
\hline 1 & {$[-1]$} & {$\left[\begin{array}{ll}* & ]\end{array}\right.$} & Neadekvátní \\
\hline 2 & & {$\left[\begin{array}{ll}* * & ]\end{array}\right.$} & NYNÍ NEPOUŽÍVÁNO \\
\hline 3 & {$\left[\begin{array}{ll}0 & 0\end{array}\right]$} & {$\left[{ }^{* * *}\right]$} & Adekvátní nebo přiměřený \\
\hline 4 & [ 1 ] & {$\left[{ }^{* * * *}\right]$} & Dobrý \\
\hline \multirow[t]{2}{*}{5} & [ 2 ] & {$[* * * * *]$} & Vynikající \\
\hline & & $\begin{array}{c}\text { [N.r.i.o.r] }{ }^{*} \text { (pouze pro } \\
\text { aktualizace) }\end{array}$ & $\begin{array}{l}\text { Položka nebyla v původní } \\
\text { recenzi posuzována }\end{array}$ \\
\hline
\end{tabular}

V této části má být provedeno více hodnocení různých aspektů nebo atributů dokumentace dodávané s nástrojem (nebo balíkem). Termín „dokumentace“ byl vybrán, aby pokrýval všechny ty materiály dodávané s nástrojem nebo snadno dostupné kvalifikovanému uživateli: např. manual administrátora; technické prŕručky; brožury s normami; dodatky k manuálu; aktualizace od vydavatelů/dodavatelů atd. 
Položky mají být posuzovány n/a nebo 0 až 5 (poloviční rating je přijatelný)

\section{Rating}

\begin{tabular}{|c|c|c|}
\hline \multicolumn{2}{|c|}{$\begin{array}{l}\text { Kvalita vysvětlení principů, prezentace a kvalita poskytnuté informace: } \\
\text { (Tento celkový rating se získá použitím posouzení založeného na ratinzích daných pro položky } 2.1-2.8 \text { ) }\end{array}$} & \multirow{2}{*}{3,5} \\
\hline 2.1 & $\begin{array}{l}\text { Celkový rating kvality vysvětlení principů: (Tento celkový rating se získá použitím } \\
\text { posouzení založeného na hodnotách ratingů daných pro položky } 2.1 .1-2.1 .5)\end{array}$ & \\
\hline 2.1 .1 & i) Teoretické základy konstruktů: & 3 \\
\hline 2.1 .2 & ii) Procedura vývoje testu: & 3 \\
\hline 2.1 .3 & iii) Důkladnost analýz položek a model analýzy položek: & 0 \\
\hline 2.1 .4 & iv) Vysvětlení obsahové validity: & 1 \\
\hline 2.1 .5 & v) Souhrn relevantního výzkumu: & 1 \\
\hline 2.2 & $\begin{array}{l}\text { Adekvátnost dokumentace dostupné uživateli (uživatelské a technické } \\
\text { manuály, dodatky týkající se norem atd.): (Tento celkový rating se získá použitím } \\
\text { posouzení založeného na hodnotách ratingů daných pro položky } 2.2 .1-2.2 .6 \text { ) } \\
\text { Pro část } 2.2 \text { jsou stanoveny následující „měřítka“ pro rating „vynikající“ (5). Pozornost je zde zaměřena } \\
\text { na kvalitu pokrytí poskytnutého v dokumentaci dostupné kvalifikovaným uživatelüm. Všimněte si, že část } \\
2.2 \text { se týká úplnosti a jasnosti dokumentace dostupné uživateli (uživatelské a technické manually, doadtky } \\
\text { k normám atd.) v pojmech pokrytí a vysvětlení. V pojmech kvality nástroje, jak ji dosvědčuje dokumentace, } \\
\text { jsou rozpracovány oblasti v této části pod čísly: } 2.1,2.3,2.9,2.10 \text { a } 2.11 \text {. }\end{array}$ & 3,5 \\
\hline 2.2 .1 & $\begin{array}{l}\text { Principy: [viz 2.1] } \\
\text { Dobře argumentovaný a jasně prezentovaný popis toho, co má podle návrhu měřit a proč byl zkonstruován } \\
\text { tak, jak je. }\end{array}$ & 3 \\
\hline 2.2 .2 & $\begin{array}{l}\text { Vývoj: } \\
\text { Úplné detaily týkající se zdrojů položek, pilotáže, analýz položek, srovnávacích studií a změn prováděných v } \\
\text { prủběhu vývojových pokusŭ. }\end{array}$ & 1,5 \\
\hline 2.2 .3 & $\begin{array}{l}\text { Standardizace: } \\
\text { Jasné a detailní informace poskytnuté o velikostech a zdrojích standardizačního souboru a standardizační } \\
\text { proceduře. }\end{array}$ & 5 \\
\hline 2.2 .4 & $\begin{array}{l}\text { Normy: } \\
\text { Jasné a detailní informace poskytnuté o velikostech a zdrojích normalizačních skupin, podmínkách vyšetření } \\
\text { atd. }\end{array}$ & 4 \\
\hline 2.2 .5 & $\begin{array}{l}\text { Reliabilita: } \\
\text { Dobré vysvětlení reliability a široký rozsah měr vnitřní konsistence a retestu spolu s vysvětlením jejich } \\
\text { relevance a zobecnitelnosti nástroje vyšetření. }\end{array}$ & 1,5 \\
\hline 2.2 .6 & $\begin{array}{l}\text { Validita: } \\
\text { Dobré vysvětlení validity spolu s širokou škálou studií jasně a poctivě popsaných. }\end{array}$ & 3 \\
\hline 2.3 & $\begin{array}{l}\text { Kvalita procedurálních instrukcí poskytnutých uživateli: (Tento celkový rating se } \\
\text { získá s použitím posouzení na základě hodnot ratingů daných pro položky } 2.3 .1-2.3 .7 \text { ) }\end{array}$ & 3 \\
\hline 2.3 .1 & $\begin{array}{l}\text { Pro administraci testu: } \\
\text { Poskytnutá jasná a detailní vysvětlení a procedurální průvodce krok za krokem spolu s dobrými radami } \\
\text { týkajícícmi se otázek uchazeču a problémových situací. }\end{array}$ & 5 \\
\hline 2.3 .2 & $\begin{array}{l}\text { Pro skórování testu, normy atd.: } \\
\text { Poskytnuté jasné a detailní informace spolu s popsanými kontrolami pro vyhnutí se možným chybám } \\
\text { skórování. }\end{array}$ & 4 \\
\hline 2.3 .3 & $\begin{array}{l}\text { Pro interpretaci a vytváření zpráv: } \\
\text { Detailní doporučení týkající se interpretace různých skórů, chápání normativních měr a zacházení se vztahy } \\
\text { mezi rưznými škálami, s množstvím ilustrativních příkladů a př́padových studií. }\end{array}$ & 1,5 \\
\hline 2.3 .4 & $\begin{array}{l}\text { Pro poskytnutí zpětné vazby a debriefingu respondentům testu a dalším: } \\
\text { Detailní doporučení, jak prezentovat zpětnou vazbu uchazečům. }\end{array}$ & 0 \\
\hline 2.3 .5 & $\begin{array}{l}\text { Pro poskytování dobrých praktických témat týkajících se poctivosti a } \\
\text { zkreslení: } \\
\text { Uvedení detailních informací o studiích sexuálního a etnického zkreslení s relevantními varováními týkajícími } \\
\text { se používání a zobecňování validit. }\end{array}$ & 0 \\
\hline 2.3 .6 & $\begin{array}{l}\text { Omezení používání: } \\
\text { Jasné popisy, kdo by měl a kdo by neměl být vyšetřován spolu s dobře vysvětlenými odůvodněními těchto } \\
\text { omezení (např. typy nezpưsobilostí, požadované úrovně gramotnosti atd.). }\end{array}$ & 3 \\
\hline 2.3 .7 & $\begin{array}{l}\text { Reference a podpůrné materiály: } \\
\text { Detailní odkazy na relevantní podpůrnou akademickou literature a křížové odkazy na další příbuzné } \\
\text { materially týkající se diagnostických nástrojü. }\end{array}$ & 3 \\
\hline $\begin{array}{l}\text { Kva } \\
\text { (Ten }\end{array}$ & $\begin{array}{l}\text { materiálů: } \\
\text { ový rating se získá použitím posouzení založeného na hodnotách ratingů pro položky } 2.4-2.8 \text { ) }\end{array}$ & 5 \\
\hline
\end{tabular}




\begin{tabular}{|l|l|c|}
\hline 2.4 & $\begin{array}{l}\text { Všeobecná kvalita materiálů testu } \\
\text { (testové brožury, odpověd'ové archy, testové objekty, software atd.): }\end{array}$ & 5 \\
\hline 2.5 & Kvalita lokální adaptace testu (pokud byl test přeložen a adaptován do místního jazyka): & {$[\mathrm{n} / \mathrm{a}]$} \\
\hline 2.6 & Snadnost, s jakou může respondent testu porozumět úkolu: & 5 \\
\hline 2.7 & $\begin{array}{l}\text { Snadnost, s jakou mohou být respondentem testu tvořeny reakce nebo } \\
\text { odpovědi: }\end{array}$ & 5 \\
\hline 2.8 & Kvalita položek: & 5 \\
\hline $\begin{array}{l}\text { Recenzentovy komentáře týkající se dokumentace: } \\
\text { (komentáře principů, designu, vývoje testu a jeho přijatelnosti) }\end{array}$ & \\
\hline
\end{tabular}

Manuál je přehledně členěn do kapitol. Úvodní kapitola představuje vývoj pozornosti v předškolním věku a př́buzné metody, ze kterých nově vyvinutá metoda vychází. Následující kapitola se věnuje př́mo Barevnému testu cesty pro děti. $V$ této části je uvedeno věkové rozmezí, forma testu a skórování, trvání administrace a vyhodnocení, podoba testu, standardizace, validita a reliabilita. $\mathrm{V}$ poslední kapitole jsou informace $\mathrm{k}$ administraci, včetně konkrétních slovních instrukcí. $\mathrm{V}$ př́lohách najdeme normalizační tabulky, záznamový list pro administrátora a tabulku interkorelací jednotlivých úkolů testu.

V teoretickém úvodu by mohly být prezentované informace lépe propojovány s konkrétním využitím při vývoji testu. Vývoj pozornosti a dalších kognitivních funkcí, které se k ní vážou, je vzhledem $\mathrm{k}$ metodě přiléhavý, ale bohužel zůstává nejasné, jak přesně se tato teorie promítla do vývoje metody a zejména podnětového materiálu. Stejný dojem budí část představující př́ibuzné nástroje.

\section{Část 7: \\ Hodnocení norem, reliability a validity}

\section{Informace o normách nebo referenční skupině}

\begin{tabular}{|c|c|c|}
\hline 2.9 & Celková adekvátnost: & 3,5 \\
\hline 2.9 .1 & $\begin{array}{l}\begin{array}{l}\text { Vhodnost pro lokální použití, at' už pro lokální nebo mezinárodní normy: } \\
{[\mathrm{n} / \mathrm{a}]}\end{array} \\
\begin{array}{l}\text { Nepoužitelné } \\
1\end{array} \\
\begin{array}{l}\text { Žádná informace nepodána. } \\
\text { Není lokálně relevantní (např. nevhodné zahraniční výběry). }\end{array} \\
\begin{array}{l}\text { Lokální výběr z obecné populace nebo nelokální normy, které lze } \\
\text { použít s varováním. }\end{array} \\
\begin{array}{l}\text { Výběry lokální země nebo relevantní mezinárodní výběry s dobrou } \\
\text { relevancí pro zamýšlenou aplikaci. }\end{array} \\
\begin{array}{l}\text { Výběry lokální zemé nebo relevantní mezinárodní výběry vybrané z } \\
\text { dobře definovaných výběrů z relevantních aplikačních oblastí. }\end{array}\end{array}$ & 4 \\
\hline
\end{tabular}




\begin{tabular}{|c|c|c|c|}
\hline 2.9 .2 & $\begin{array}{cc}\text { Vhodnost pro zam } \\
\text { [n/a] } & \mathrm{N} \\
0 & \mathrm{ZZ}_{\mathrm{a}} \\
1 & \mathrm{~N} \\
3 & \mathrm{Ac} \\
& \text { ta } \\
4 & \mathrm{D} \\
5 & \mathrm{Vy} \\
& \mathrm{a} \\
& \mathrm{s} \\
& \mathrm{s} \\
\end{array}$ & $\begin{array}{l}\text { nýšlené aplikace: } \\
\text { Nepoužitelné } \\
\text { Žádná informace nepodána. } \\
\text { Norma nebo normy nejsou adekvátní pro zamýšlené aplikace. } \\
\text { Adekvátní normy pro obecnou populaci a/nebo rozmezí normativních } \\
\text { tabulek. } \\
\text { Dobré rozmezí normativních tabulek. } \\
\text { Vynikajíć rozmezí výběrově relevantních norem vztahujících se k věku } \\
\text { a pohlaví, s informacemi o dalších rozdílech v rámci skupin (např. } \\
\text { směs etnických skupin). }\end{array}$ & 4 \\
\hline 2.9 .3 & $\begin{array}{cc}\text { Velikosti výběrů: } \\
\text { [n/a] } & \mathrm{N} \\
0 & \check{Z}_{\mathrm{a}} \\
1 & \mathrm{~N} \\
3 & \mathrm{Ac} \\
4 & \mathrm{~V} c \\
5 & \mathrm{Vc}\end{array}$ & $\begin{array}{l}\text { Nepoužitelné } \\
\text { Žádná informace nepodána. } \\
\text { Neadekvátní výběry (např. méně než 150). } \\
\text { Adekvátní výběry (např. 150-300). } \\
\text { Velké výběry (např. 300-1000). } \\
\text { Velmi velké výběry (např. 1000+). }\end{array}$ & 3 \\
\hline 2.9 .4 & $\begin{array}{cr}\text { Procedury použité } \\
\text { (vyberte jednu a ohodnc } \\
\square & \mathrm{Z}_{\text {c }} \\
\square & \mathrm{Re} \\
\square & \mathrm{N} \\
\square & \mathrm{N} \\
\end{array}$ & $\begin{array}{l}\text { té při výběru souboru: } \\
\text { not'te kvalitu použitého postupu) } \\
\text { Žádná informace neposkytnuta } \\
\text { Reprezentativní populaci [sumarizujte kritéria] } \\
\text { Nahodilá } \\
\text { Náhodná }\end{array}$ & 4 \\
\hline 2.9 .5 & $\begin{array}{cr}\text { Kvalita informací } \\
\text { vlivech věku, rodu } \\
\text { [n/a] } & \mathrm{N} \\
0 & \mathrm{Z}_{\mathrm{a}} \\
1 & \mathrm{~N} \\
3 & \mathrm{Ac} \\
4 & \mathrm{D} \\
5 & \mathrm{VJ} \\
& \mathrm{se}\end{array}$ & $\begin{array}{l}\text { poskytnutých o minoritní/chráněné skupině, rozdílech, } \\
\text { u atd.: } \\
\text { Nepoužitelné } \\
\text { Žádná informace nepodána. } \\
\text { Neadekvátní informace. } \\
\text { Adekvátní obecné informace s minimální analýzou. } \\
\text { Dobré popisy a analýzy skupin a rozdílu } \\
\text { Vynikajíćí série analýz a diskuse o relevantních tématech vztahujících } \\
\text { se k použití a interpretaci. }\end{array}$ & 3 \\
\hline \multicolumn{4}{|c|}{$\begin{array}{l}\text { 2.9.6 Komentáře recenzentů k normám: Stručná zpráva o normách a jejich historii, včetně informací o doporučeních } \\
\text { učiněných vydavatelem/autorem pro aktualizaci norem obvyklým zpưsobem. }\end{array}$} \\
\hline \multicolumn{4}{|c|}{$\begin{array}{l}\text { Normy byly vytvořeny na standardizačním vzorku } 273 \text { dětí ve věku od } 5 \text { do } 7 \text { let. Byl zjišt'ován přesný } \\
\text { věk probandů (roky, měsíce, dny), aby mohly být následně vytvořeny normy pro skupiny vždy po šesti } \\
\text { měsících věku. Normy byly vytvořeny pro čtyři věkové kategorie }(5 ; 0 ; 0-5 ; 6 ; 30,5 ; 7 ; 0-5 ; 11 ; 30,6 ; 0 ; 0- \\
6 ; 6 ; 30 \text { a } 6 ; 7 ; 0-6 ; 11 ; 30) \text {. Zastoupení dětí bylo ve všech skupinách podobné. Normy jsou společné pro } \\
\text { dívky a chlapce, v manuálu jsme však nenašly informace o kontrole vlivu pohlaví. } \\
\text { Sběr dat probíhal v mateřských a základních školách v deseti městech a obcích z různých krajů České } \\
\text { republiky. Autorky se snažily zajistit rovnoměrné zastoupení pohlaví a respektovat populační } \\
\text { zastoupení různých velikostí bydliště. Ve standardizačním vzorku bylo nakonec oproti obecnému } \\
\text { populačnímu trendu více dětí z malých obcí, ale následná analýza ukázala, že by velikost bydliště } \\
\text { neměla hrát významnou roli. Ačkoliv se autorky snažily získat vzorek, který dobře odpovídá } \\
\text { uvažované populaci, nejedná se o reprezentativní vzorek, ale spíše o nahodilý kvótní výběr. }\end{array}$} \\
\hline
\end{tabular}

\section{Validita}

\begin{tabular}{|l|l|c|}
\hline 2.10 & $\begin{array}{l}\text { Celková adekvátnost: (Tento celkový rating se získá na základě posouzení hodnot ratingů } \\
\text { daných v položkách 2.10.1 - 2.10.2.4. Neprüměrujte pouze čísla, abyste získali celkový rating. } \\
\text { obvykle bude roven bud' konstruktové validitě nebo validitě vztahující se ke kritériu, podle } \\
\text { toho, která z nich je vyšší.) }\end{array}$ & $\mathbf{3}$ \\
\hline 2.10 .1 & $\begin{array}{l}\text { Konstruktová validita - celková adekvátnost } \\
\text { (Tento celkový rating se získá na základě posouzení hodnot ratingů daných v položkách } \\
\text { 2.10.1.2 - 2.10.1.6. Neprưměrujte pouze čísla, abyste tento celkový rating získali.) }\end{array}$ & $\mathbf{3}$ \\
\hline
\end{tabular}




\begin{tabular}{|c|c|c|c|}
\hline 2.10 .1 .1 & $\begin{array}{r}\text { Použité } \\
\square \\
\square \\
\square \\
\square \\
\square \\
\square \\
\square \\
\square \\
\square\end{array}$ & $\begin{array}{l}\text { lány: (zatrhněte tolik, kolik je jich použitelných) } \\
\text { Žádná informace nepodána } \\
\text { Korelace s dalšími nástroji a výkonovými kritérii } \\
\text { Vnitroškálový (korelace položky se zbytkem) } \\
\text { Rozdíly mezi skupinami } \\
\text { Matice mnoha rysů a mnoha metod (MTMM) } \\
\text { Explorační faktorová analýza } \\
\text { Konfirmační faktorová analýza } \\
\text { Experimentální plány } \\
\text { Jiné: uved'te }\end{array}$ & \\
\hline 2.10 .1 .2 & $\begin{array}{c}\text { Velikost } \\
0 \\
1 \\
3 \\
4 \\
5 \\
\end{array}$ & $\begin{array}{l}\text { výběrů: } \\
\text { Žádná informace neposkytnuta. } \\
\text { Jedna neadekvátní studie (např. velikost výběru menší než 100). } \\
\text { Jedna adekvátní studie (např. velikost výběru 100-200). } \\
\text { Více než jedna adekvátní nebo velká studie. } \\
\text { Dobrá série adekvátních až rozsáhlých studií. }\end{array}$ & 3 \\
\hline 2.10 .1 .3 & $\begin{array}{c}\text { Procedu } \\
\square \\
\square \\
\square \\
\square\end{array}$ & $\begin{array}{l}\text { ca výběru souboru: (vyberte jednu) } \\
\text { Žadná informace neposkytnuta } \\
\text { Reprezentativní vůči populaci [sumarizujte kritéria] } \\
\text { Nahodilá } \\
\text { Náhodná }\end{array}$ & \\
\hline 2.10 .1 .4 & $\begin{array}{c}\text { Medián } \\
0 \\
1 \\
3 \\
4 \\
5\end{array}$ & $\begin{array}{l}\text { rozsah korelací mezi testem a dalšími podobnými testy: } \\
\text { Žádná informace neposkytnuta. } \\
\text { Neadekvátní }(\mathrm{r}<0.55) . \\
\text { Adekvátní }(0.55<\mathrm{r}<0.65) . \\
\text { Dobrý }(0.65<\mathrm{r}<0.75) . \\
\text { Vynikající }(\mathrm{r}>0.75) \\
\end{array}$ & 3 \\
\hline 2.10 .1 .5 & $\begin{array}{c}\text { Kvalita r } \\
0 \\
1 \\
3 \\
4 \\
5\end{array}$ & $\begin{array}{l}\text { ástrojů jako kritérií nebo markerů: } \\
\text { Žádná informace neposkytnuta. } \\
\text { Poskytnuta neadekvátní informace. } \\
\text { Adekvátní kvalita. } \\
\text { Dobrá kvalita. } \\
\text { Vynikající kvalita s širokým rozsahem relevantních markerů pro } \\
\text { konvergentní a divergentní validizaci. }\end{array}$ & 3 \\
\hline 2.10 .1 .6 & $\begin{array}{r}\text { Analýzy } \\
{[\mathrm{N} /} \\
0-5\end{array}$ & $\begin{array}{l}\text { diferenciálního fungování položek (DIF): } \\
\text { Nepoužitelné } \\
\text { hodnocení kvality DIF analýzy }\end{array}$ & {$[\mathrm{n} / \mathrm{a}]$} \\
\hline 2.10 .2 & $\begin{array}{l}\text { Validita } \\
\text { (Tento celk } \\
2.11 .1-2.1 \\
\end{array}$ & $\begin{array}{l}\text { vztahující se ke kritériu - celková adekvátnost } \\
\text { vý rating se získá na základě posouzení hodnot ratingů daných v položkách } \\
\text { o.2.4. Neprủměrujte pouze čísla, abyste získali celkový rating.) }\end{array}$ & $\mathbf{0}$ \\
\hline 2.10 .2 .1 & $\begin{array}{r}\text { Popis po } \\
\quad \square \\
\quad \square \\
\square\end{array}$ & $\begin{array}{l}\text { užitých kritérií a charakteristik populací: (zatrhněte tolik, kolik je pol } \\
\text { Souběžná } \\
\text { Prediktivní } \\
\text { Postdiktivní }\end{array}$ & \\
\hline 2.10 .2 .2 & $\begin{array}{c}\text { Velikos } \\
0 \\
1 \\
3 \\
4 \\
5\end{array}$ & $\begin{array}{l}\text { ti výběrů: } \\
\text { Žádná informace neposkytnuta. } \\
\text { Jedna neadekvátní studie (např. velikost výběru menší než 100). } \\
\text { Jedna adekvátní studie (např. velikost výběru 100-200). } \\
\text { Jedna velká nebo vice než jedna adekvátně rozsáhlá studie. } \\
\text { Dobrá série adekvátních až rozsáhlých studií. }\end{array}$ & 0 \\
\hline 2.10 .2 .3 & $\begin{array}{r}\text { Procedu } \\
\square \\
\square \\
\square \\
\square\end{array}$ & $\begin{array}{l}\text { ca výběru souboru: } \\
\text { Žádná informace neposkytnuta } \\
\text { Účelná nebo reprezentativní } \\
\text { Nahodilá } \\
\text { Náhodná }\end{array}$ & \\
\hline 2.10 .2 .4 & $\begin{array}{c}\text { Medián } \\
0 \\
1 \\
3 \\
4 \\
5\end{array}$ & $\begin{array}{l}\text { rozsah korelací mezi testem a kritérii: } \\
\text { Žádná informace neposkytnuta. } \\
\text { Neadekvátní (např. } \mathrm{r}<0.2 \text { ). } \\
\text { Adekvátní (např. } 0.2<\mathrm{r}<0.35 \text { ). } \\
\text { Dobrý (např. } 0.35<\mathrm{r}<0.50 \text { ). } \\
\text { Vynikající (např. } \mathrm{r}>0.50 \text { ) }\end{array}$ & 0 \\
\hline
\end{tabular}


Autorky zvolily konvergentní prŕstup k ověření validity. Jsou poskytnuty Pearsonovy koeficienty korelace BTC se skóry dalších podobně zaměřených testů - CAS2 (Plánovaná spojení), WJ-IV (Vybírání párů), IDS (Selektivní pozornost) - které se pohybují v rozmezí 0,282 až 0,664. Subtest Plánovaná spojení (CAS2) je formátu Barevného testu cesty pro děti nejpodobnější a také s ním koreluje nejsilněji. Další dva subtesty nezahrnují časovou komponentu a korelují spíše slabě. Přestože všechny čtyři testy měří pozornost, způsob měření se mezi testy liší.

Další zdroje důkazů o validitě bohužel nejsou v manuálu poskytnuty a nenašly jsme ani informace o tom, že by byly předmětem dalšího výzkumu. Na základě přiložené tabulky interkorelací jednotlivých úkolů bylo možné ověřit faktorovou strukturu proměnných, proto jsme se rozhodly tento důkaz validity doplnit alespoň pro účely této recenze. Pomocí konfirmační faktorové analýzy s odhadem metodou maximální věrohodnosti byl ověřen jednofaktorový model, kdy časy každé proměnné byly syceny jednou společnou latentní proměnnou (rychlost práce). Povolení pozitivní reziduální kovariance mezi dvěma posledními úkoly vedlo k dobré shodě modelu s daty $(C F I=0,985 ; T L I=0,976$; $S R M R=0,026 ; R M S E A=0,076 ; 90 \% C I[0,044 ; 0,108])$. Vyšší souvislost posledních dvou úkolů dává $\mathrm{z}$ teoretického hlediska smysl. Tyto úkoly obsahují větší počet složitějších podnětů, takže je potřeba více času k jejich splnění a dlouhé úlohy jsou zpracovávány jinými kognitivními systémy. U proměnné počet chyb se nepodařilo ověřit jednofaktorovou strukturu a více informací nám neposkytla ani explorační faktorová analýza. Tato proměnná však slouží pouze ke kvalitativnímu zhodnocení a nezapočítává se do celkového skóre.

\section{Reliabilita}

\begin{tabular}{|c|c|c|}
\hline 2.11 & $\begin{array}{l}\text { Celková adekvátnost: } \\
\text { (Tento celkový rating se získá na základě posouzení hodnot ratingů daných v položkách 2.11.1-2.10.2.4. } \\
\text { Neprüměrujte pouze čísla, abyste získali celkový rating.) }\end{array}$ & 4 \\
\hline 2.11.1. & $\begin{array}{cl}\text { Poskytnutá data týkající se reliability: (vyberte jednu možnost) } \\
\quad \quad \text { Uveden pouze jeden koeficient reliability } \\
\square \quad \text { Uveden pouze jeden odhad standardní chyby měření } \\
\square \quad \text { Koeficienty reliability pro několik různých skupin } \\
\square \quad \text { Standardní chyba měření uvedená pro několik různých skupin }\end{array}$ & \\
\hline 2.11 .1 & Vnitřní konzistence: & \\
\hline 2.11.1.1 & $\begin{array}{cl}\text { Velikost výběru: } \\
0 & \text { Neposkytnuta žádná informace. } \\
1 & \text { Jedna neadekvátní studie (napr. rozsah výběru menší než 100). } \\
3 & \text { Jedna adekvátní studie (např. rozsah výběru 100-200). } \\
4 & \text { Jedna rozsáhlá nebo vice než jedna adekvátně rozsáhlá studie. } \\
5 & \text { Dobrá série adekvátních až rozsáhlých studií. } \\
{[\mathrm{N} / \mathrm{A}]} & \text { Nepoužitelné. } \\
\end{array}$ & 0 \\
\hline 2.11 .1 .2 & $\begin{array}{cl}\text { Medián koeficientů: } \\
0 & \text { Neposkytnuta žádná informace. } \\
1 & \text { Neadekvátní (např. } \mathrm{r}<0.7 \text { ) } \\
3 & \text { Adekvátní (např. } \mathrm{r}=0.7 \text { až } 0.79 \text { ) } \\
4 & \text { Dobrý (např. } \mathrm{r}=0.8 \text { až } 0.89 \text { ) } \\
5 & \text { Vynikající (např. r }>0.9 \text { ) } \\
{[\mathrm{N} / \mathrm{A}]} & \text { Nepoužitelné. } \\
\end{array}$ & 4 \\
\hline 2.11 .2 & Testová-retestová stabilita: & \\
\hline 2.11.2.1 & $\begin{array}{cl}\text { Rozsah výběru: } & \\
0 & \text { Neposkytnuta žádná informace. } \\
1 & \text { Jedna neadekvátní studie (např. rozsah výběru menší než 100). } \\
3 & \text { Jedna adekvátní studie (např. rozsah výběru 100-200). } \\
4 & \text { Jedna rozsáhlá nebo vice než jedna adekvátně rozsáhlá studie. } \\
5 & \text { Dobrá série adekvátních až rozsáhlých studií. } \\
\end{array}$ & 1 \\
\hline 2.11 .2 .2 & $\begin{array}{cl}\text { Medián koeficientů: } \\
0 & \text { Neposkytnuta žádná informace. } \\
1 & \text { Neadekvátní (např. } \mathrm{r}<0.6 \text { ) } \\
3 & \text { Adekvátní (např. } \mathrm{r}=0.6 \text { až } 0.69 \text { ) } \\
4 & \text { Dobrý (např. } \mathrm{r}=0.7 \text { až } 0.79 \text { ) } \\
5 & \text { Vynikající (např. } \mathrm{r}>0.8 \text { ) } \\
\end{array}$ & 3 \\
\hline
\end{tabular}




\begin{tabular}{|c|c|c|c|}
\hline 2.11 .3 & \multicolumn{3}{|c|}{ Reliabilita jako ekvivalence: } \\
\hline 2.11 .3 .1 & $\begin{array}{l}\text { Rozsah výběru: } \\
\quad 0 \\
1 \\
3 \\
4 \\
5 \\
{[\mathrm{~N} / \mathrm{A}]}\end{array}$ & $\begin{array}{l}\text { Neposkytnuta žádná informace. } \\
\text { Jedna neadekvátní studie (např. rozsah výběru menší než 100). } \\
\text { Jedna adekvátní studie (napřr. rozsah výběru 100-200). } \\
\text { Jedna rozsáhlá nebo vice než jedna adekvátně rozsáhlá studie. } \\
\text { Dobrá série adekvátních až rozsáhlých studií. } \\
\text { Nepoužitelné. }\end{array}$ & {$[\mathrm{n} / \mathrm{a}]$} \\
\hline 2.11.3.2 & $\begin{array}{l}\text { Medián koeficie } \\
\quad 0 \\
1 \\
3 \\
4 \\
5 \\
{[\mathrm{~N} / \mathrm{A}]} \\
\end{array}$ & $\begin{array}{l}\text { ntů: } \\
\text { Neposkytnuta žádná informace. } \\
\text { Neadekvátní (např. } r<0.6 \text { ) } \\
\text { Adekvátní (např. } r=0.6 \text { až } 0.69 \text { ) } \\
\text { Dobrý (např. } r=0.7 \text { až } 0.79 \text { ) } \\
\text { Vynikající (např. } r>0.8 \text { ) } \\
\text { Nepoužitelné }\end{array}$ & {$[\mathrm{n} / \mathrm{a}]$} \\
\hline \multicolumn{4}{|c|}{$\begin{array}{l}\text { 2.11.4 Komentáře recenzentů k reliabilitě: } \\
\text { - Komentujte intervaly spolehlivosti pro koeficienty reliability } \\
\text { - Uved'te Spearmanovy-Brownovy ekvivalenty }\end{array}$} \\
\hline \multicolumn{4}{|c|}{$\begin{array}{l}\text { Reliabilita byla ověřována z hlediska stability v čase. S odstupem } 20 \text { až } 40 \text { dní bylo u } 24 \text { dětí } \\
\text { provedeno opakované měření. Hodnota test-retestové reliability byla r=0,68, což podle autorek značí } \\
\text { silnou závislost mezi jednotlivými měřeními. My bychom ji hodnotily jako adekvátní a zdůraznily } \\
\text { bychom limit malého vzorku. } \\
\text { Pomocí neparametrického Wilcoxonova párového testu a testu znaménkového byly zjištěny } \\
\text { signifikantní rozdíly mezi prvním a druhým měřením. Došlo ke zrychlení prủměrného času ze } 193 \mathrm{~s} \\
\text { na } 181 s, \text { pravděpodobně díky zácviku či předchozí zkušenosti s testovou situací. Chybovost byla } \\
\text { nezávislá na opakovaných měření a hodnota test-retestové reliability počtu chyb byla r=0,48. Tyto } \\
\text { informace je třeba brát v potaz při zvažování užití testu pro opakovaná měření. Měsíční odstup je } \\
\text { možná příliš krátký interval, a proto by budoucí výzkum mohl zkusit ověřit, zda tento efekt přetrvává } \\
\text { i po delší době. } \\
\text { Autorky usuzují na vysokou vnitřní konzistenci z toho, že děti, které odpovídaly rychleji v lehčích } \\
\text { úkolech, byly rychlejší i v těžších úkolech (a naopak). Odkazují se na tabulku inter-korelací mezi } \\
\text { jednotlivými úkoly, která je uvedena v přílohách. Na základě této tabulky jsme vypočetly } \\
\text { standardizovanou Cronbachovu alfu, čímž jsme se ujistily o vysoké vnitřní konzistenci o hodnotě } 0,92 \\
\text { v případě rychlosti plnění úkolů a uspokojivé reliabilitě } 0,79 \text { v př́padě chybovosti. Výpočet je založen } \\
\text { na datech celého vzorku } 273 \text { dětí, ale } s \text { ohledem na to, že autorky koeficienty neuvádí, hodnotíme } \\
\text { oddíl } 2.11 .1 .1 \text { nulou. Také chceme upozornit, že vypočtené hodnoty reliability se vztahují na celý } \\
\text { vzorek. Vzhledem k předpokládanému vlivu věku na výkon pozornosti mủže být tento odhad } \\
\text { nadhodnocený oproti hodnotám reliabilit uvnitř jednotlivých kohort, které není možné z dostupných } \\
\text { dat dopočítat. Z toho důvodu uvádíme hodnocení odpovídající vnitřní konzistenci } 0,8 \text { až } 0,89 \text {. }\end{array}$} \\
\hline
\end{tabular}

\section{Č́st 9:}

\section{Závěrečné hodnocení:}

\subsection{Hodnotící zpráva testu: \\ Tato část by měla obsahovat stručné, jasně obhájené posouzení nástroje/produktu. Mělo by popisovat jeho pro a proti a poskytnout určitá obecná doporučení týkající se toho, jak a kdy by se měl používat - spolu s varováními (kde jsou potřebná) týkajícími se případů, kde by se používat neměl.}

Screeningová metoda Barevný test cesty pro děti je určena pro děti od 5 do 7 let, v čemž spatřujeme hlavní silnou stránku této metody. $V$ českém prostředí nebyl k dispozici podobný test, který by se zaměřoval na rychlé zhodnocení pozornosti dětí v této věkové skupině. BTC je dle našeho názoru 
podobný alternativě TMT - Children's Color Trail Test, který bohužel není dostupný v ČR. V obou testech mají děti za úkol spojovat barevná kolečka, u obou testů je skórem čas, dítě je podporováno k co nejrychlejší práci po absolvovaném zácviku, počet chyb je zaznamenáván, avšak není skórován. Testy však cílí na jinou věkovou populaci. CCTT je určen až pro děti od 8 let, protože je nutná znalost číslic. BTC je založen na spojování koleček pouze na základě různých barev a vzorů, bez přítomnosti číslic. Z našeho pohledu však může být podnětový materiál BTC paradoxně náročnější (zejména poslední úkoly) a mohl by mít potenciál i pro standardizaci pro starší populaci.

Výhodu metody spatřujeme $v$ tom, že vznikala př́mo v prostředí ČR a díky standardizaci vznikly normy na českém vzorku dětí, i když ne zcela reprezentativním. Tyto normy jsou dostupné v manuálu. Manuál metody je přehledný, díky čemuž je umožněna dobrá orientace v textu. Součástí manuálu jsou podrobné informace $\mathrm{k}$ administraci, včetně znění přesné instrukce pro administraci. Informace poskytnuté $\mathrm{k}$ validitě a reliabilitě hodnotíme jako adekvátní, nicméně k těmto sekcím by dle našeho názoru bylo vhodné doplnit více důkazů.

Slabou stránku metody spatřujeme $\mathrm{v}$ některých chybějících údajích, které bychom pro komplexnější pohled ocenily. $\mathrm{V}$ manuálu nejsou explicitně uvedeny údaje o tom, $\mathrm{v}$ kterých všech oblastech lze metodu využít. Obecně nám zde chybí část věnující se samostatně záměru testu. Ten lze odvozovat z poskytnutých informací např́č manuálem, nicméně tato oblast by si zasloužila samostatný ucelený prostor. Stejně tak chybí informace $\mathrm{k}$ vlastnímu vývoji úkolů v testu. $\mathrm{K}$ vývoji testu jsou poskytnuty pouze informace o původním testu TMT a jeho alternativách (např. Children's Color Trail Test), ze kterých BTC vychází. Prezentované informace by mohly být lépe propojovány s jejich konkrétní aplikací (viz výše). Při administraci je doporučeno kromě času zaznamenávat také počet chyb $\mathrm{k}$ následnému kvalitativnímu posouzení, ale bližší informace $\mathrm{k}$ jejich interpretaci nejsou uvedeny. Za problémové považujeme, že autorky nezvažují chybu měření a její zapojení do intepretace výsledků testu. Není uveden ani koeficient vnitřní konzistence testu. Autorky v manuálu usuzují na vnitřní konzistenci testu na základě tabulky interkorelací položek, ze které lze dopočítat koeficient pro celý vzorek, ale ne pro jednotlivé kohorty.

I přes uvedené nedostatky hodnotíme Barevný test cesty pro děti jako kvalitní nástroj pro screeningové vyšetření pozornosti dětí od 5 do 7 let, který umožňuje rychlé prvotní posouzení výkonu pozornosti těchto dětí. Před administrací testu je nutné pečlivě prostudovat manuál a instrukce $\mathrm{k}$ administraci, aby nedošlo ke zkreslení výsledku administrátorem. Kvalifikační požadavky nejsou uvedeny. Co se týče profesionální kvalifikace, vydavatel uvádí, že podmínkou používání nástroje je licence $\mathrm{B}$, tj. absolventi bakalářského stupně psychologie a specialisté z prŕ́buzných oborů. Nastavené požadavky dle našeho názoru odpovídají náročnosti kladené na administrátora.

Tento test je dostupný na stránkách vydavatele Propsyco, s.r.o. za pořizovací cenu 854,70 Kč včetně DPH. Vydavatel nás informoval, že jedno kompletní balení metody obsahuje př́ruččku a 30 ks testových sešitů. K administraci je třeba pro každé dítě vlastní testový sešit s úkoly a záznamový arch (dostupný v př́llohách př́ručky). Za počáteční náklady je možné vyšetřit 30 dětí. Na stránkách vydavatele lze dokoupit testové sešity (435 Kč včetně DPH, 30 ks).

\subsection{Závěry:}

Barevný test cesty pro děti je podle nás vhodným nástrojem pro zamýšlené účely, tj. screeningové vyšetření pozornosti u dětí ve věku od 5 do 7 let. Nízký skór v testu nelze s aktuálními normami nijak blíže interpretovat a měl by tedy sloužit pouze jako doporučení pro komplexnější diagnostiku pozornosti a exekutivních funkcí. Administrace je nenáročná a instrukce pro administrátora poskytnuté v manuálu jsou z našeho pohledu přehledné a dostačující. Skórování testu je do velké míry nezávislé na osobě administrátora, ale jelikož v manuálu chybí informace k doporučenému obsahu či formátu zpětné vazby, administrátoři by měli skutečně dbát na to, že výsledek testu je spíše orientačním ukazatelem. S vědomím výše uvedených omezení je možné metodu použít způsobem, který uvádí vydavatel metody. 


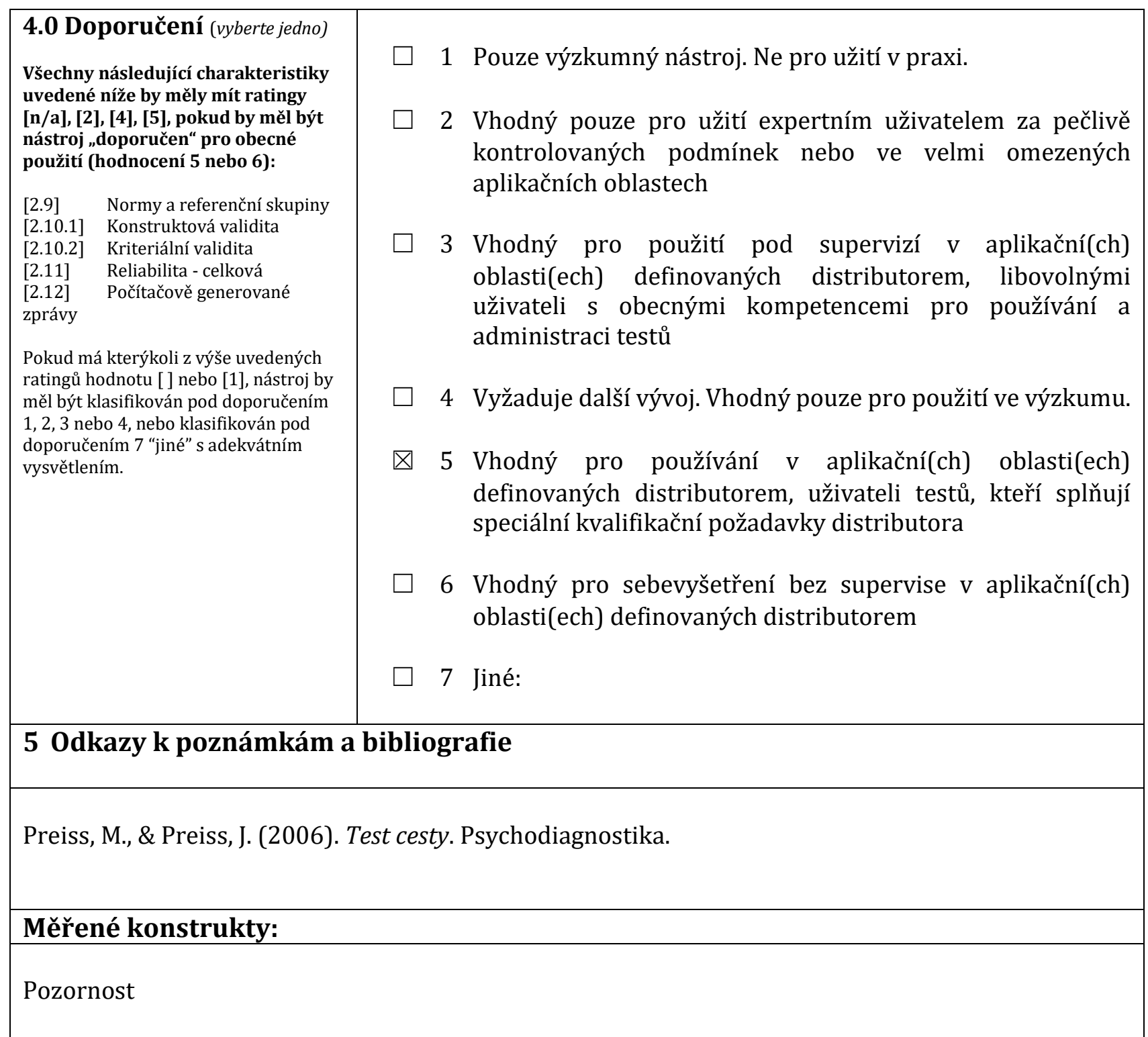

